\title{
PERSEPSI KONSUMEN TERHADAP BAURAN PEMASARAN PADA PRODUK DAGING SAPI SEGAR DI WARUNG PANGAN SEHAT KOTA BOGOR
}

\author{
${ }^{1)}$ Wawan Hari Subagyo, ${ }^{2)}$ Ari Widiyastuti \\ ${ }^{1)}$ Dosen Program StudiManajemen, STIE Dewantara \\ Jl. Raya PemdaBojongDepokBaru III, Karadenan, Cibinong,Bogor, Jawa Barat 16913,Indonesia \\ Email: wawan.hari@dewantara.ac.id \\ ${ }^{2)}$ Alumni Program StudiManajemen, STIE Dewantara \\ J1. Raya PemdaBojongDepokBaru III, Karadenan, Cibinong, Bogor, Jawa Barat 16913,Indonesia \\ Email: arhiewidia@gmail.com
}

\begin{abstract}
The purpose of this study was to determine how consumers' perceptions of the marketing mix of fresh beef products at Warung Pangan Sehat. This type of research uses descriptive quantitative. The sampling technique used is accidental sampling technique. Determination of the sample using the Slovin formula so that the sample obtained is 100 respondents. And data analysis techniques using the tools SPSS and WMS.Based on the results of the analysis discussion using the Weight Mean Score (WMS). The results of the assessment of the condition of each variable, namely the criterion product variable are very good with an average value of 3.48 , the criteria promotion variable is very good with an average value of 3.42 , the criteria price variable is very good with an average value of 3.35, the location variable very good criteria with an average value of 3.31. The highest average interpretation value is on the product variable with a value of 3.48 which is in the very good interpretation criteria. Consumers have perception that fresh beef products at Warung Pangan Sehat are very good. While the lowest average interpretation value is on the location variable with a value of 3.31 which means that the interpretation is very good. Consumers have a perception that the location of Warung Pangan Sehat is still accessible to consumers. The average interpretation value of all indicators is 3.39 which means very good. Overall, consumer perceptions of fresh beef products and promotions carried out are very good, the prices offered and the locations of Warung Pangan Sehat are affordable to consumers.
\end{abstract}

Keywords: Marketing mix, Quantitative Descriptive, Bogor City's Healthy Food Stalls.

\begin{abstract}
ABSTRAK
Tujuan dari penelitian ini adalah mengetahui bagaimana persepsi konsumen terhadap bauran pemasaran pada produk daging sapi segar di Warung Pangan Sehat. Jenis Penelitian ini menggunakan kuantitatif deskriptif. Teknik pengumpulan data yang digunakan adalah teknik accidental sampling. Penentuan sampel menggunakan rumus slovin sehingga sampel yang diperoleh adalah 100 responden. Dan teknik analisis data menggunakan alat bantu SPSS dan WMS. Berdasarkan hasil pembahasan analisis menggunakan Weight Mean Score (WMS). Hasil penilaian persepsi konsumen pada tiap variabel yaitu variabel produk sangat baik dengan nilai rata-rata 3,48, variabel promosi sangat baik dengan nilai rata-rata 3,42, variabel harga sangat baik dengan nilai rata-rata 3,35, variabel lokasi sangat baik dengan nilai rata-rata 3,31. Nilai rata-rata persepsi tertinggi yaitu pada variabel produk dengan nilai sebesar 3,48 dengan kriteria sangat baik. Konsumen memiliki persepsi produk daging sapi segar yang dijual di Warung Pangan Sehat adalah sangat baik. Sedangkan nilai rata-rata persepsi terendah yaitu variabel lokasi dengan nilai sebesar 3,31 dengan kriteria sangat baik. Konsumen memiliki persepsi lokasi Warung Pangan Sehat masih memungkinkan dijangkau konsumen. Nilai ratarata penafsiran seluruh variabel yaitu sebesar 3,39 dengan kriteria sangat baik. Secara keseluruhan, persepsi konsumen terhadap produk daging sapi segar dan promosi yang dilakukan sangat baik, harga yang ditawarkan dan lokasi Warung Pangan Sehat terjangkau konsumen.
\end{abstract}

Kata kunci: Bauran pemasaran, Deskriptif Kuantitatif, Warung Pangan Sehat Kota Bogor. 


\section{PENDAHULUAN}

\subsection{Landasan Teori}

Bauran pemasaran merupakan salah satu konsep kunci dalam teori pemasaran modern yang terdiri dari variabel produk, promosi, harga, dan tempat yang dapat dikendalikan oleh perusahaan (Kotler dan Armstrong, 2012). Keempat variabel ini menjadi hal yang sangat penting dan selalu menjadi pertimbangan konsumen dalam mengambil keputusan pembelian. Keunggulan-keunggulan produk dari keempat faktor ini dapat diketahui oleh konsumen dan membuat konsumen tertarik untuk mencoba dan kemudian akan mengambil keputusan untuk membeli suatu produk tersebut.

Warung Pangan Sehat suatu perusahaan yang bergerak di Retail Bahan Pangan yang didirikan pada Bulan Juni 2017.

Tabel 1. Data Penjualan Daging Sapi di Warung Pangan Sehat Kota Bogor Tahun 2019

\begin{tabular}{|c|c|}
\hline Bulan & $\begin{array}{c}\text { Data Penjualan } \\
\text { Daging Sapi } \\
\text { (Kg/Bulan) }\end{array}$ \\
\hline Januari & 160,5 \\
\hline Februari & 235,5 \\
\hline Maret & 196,5 \\
\hline April & 195 \\
\hline Mei & 509,5 \\
\hline Juni & 832 \\
\hline Juli & 129 \\
\hline Agustus & 296 \\
\hline September & 209 \\
\hline Oktober & 161,5 \\
\hline November & 285,5 \\
\hline Desember & 165,5 \\
\hline
\end{tabular}

Sumber : Warung Pangan Sehat
Dari data tersebut diketahui konsumsi daging sapi mengalami naik turun, dan penjualan daging mengalami kenaikan pada bulan Mei sampai bulan Juni 2019, saat bulan puasa dan Hari Raya Idul Fitri.

Berikut adalah data komplain konsumen Warung Pangan Sehat, dijelaskan pada tabel 2 berikut:

Tabel 2.Komplain KonsumenWarung Pangan Sehat

\begin{tabular}{|c|c|c|}
\hline No. & Keterangan & Jumlah \\
\hline 1 & $\begin{array}{c}\text { Daging tertukar } \\
\text { dengan konsumen lain }\end{array}$ & 15 \\
2 & $\begin{array}{c}\text { Barang yang diterima } \\
\text { konsumen mengalami } \\
\text { keterlambatan }\end{array}$ & 25 \\
\hline 3 & $\begin{array}{c}\text { Timbangan daging } \\
\text { yang kurang sesuai } \\
\text { dengan pesanan }\end{array}$ & 5 \\
\hline 4 & \begin{tabular}{c} 
Harga yang tidak stabil \\
\hline
\end{tabular} \\
\hline
\end{tabular}

Dengan terjadinya naik dan turunnya penjualan, maka kami dari pihak perusahaan menyediakan daging sapi kepada masyarakat dengan menyesuaikan kebutuhan pangan daging yang sedang terjadi pada masyarakat.

Untuk dapat bersaing dan tetap bertahan sebagai penjualan daging sapi, maka selanjutnya Warung Pangan Sehat harus memilih strategi yang tepat untuk meningkatkan volume penjualan dengan memperhatikan setiap masukan atau komplain dari pembeli yang terdapat pada data tabel diatas yang menjadi acuan untuk meningkatkan penjualan di Warung Pangan Sehat. Strategi untuk mencapai target penjualan dikenal dengan sebutan Marketing Mix (Bauran Pemasaran), karena strategi tersebut digunakan untuk mempengaruhi konsumen dalam membeli suatu produk barang maupun jasa.

Keadaan pasar yang demikian menuntut perusahaan agar mampu meningkatkan keunggulan bersaing melalui implementasi konsep marketing mix 
sebagai salah satu faktor yang penting dalam meningkatkan volume penjualan dari perusahaan.

Berdasarkan uraian di atas maka peneliti tertarik untuk melakukan penelitian tentang implementasi marketing mix terhadap hal tersebut dengan judul "Persepsi Konsumen Terhadap Bauran Pemasaran Pada Produk Daging Sapi Segar di Warung Pangan Sehat Kota Bogor".

\subsection{Ruang Lingkup Masalah}

Penelitian yang berjudul Persepsi Konsumen Terhadap Bauran Pemasaran Pada Produk Daging Sapi Segar di Warung Pangan Sehat Kota Bogor ini dibatasi pada hal-hal sebagai berikut :

1. Penelitian ini dilakukan pada Konsumen Warung Pangan Sehat, Vila Bogor Indah Kota Bogor Jawa Barat.

2. Lokasi yang dibatasi Vila Bogor Indah Kota Bogor.

3. Jenis Penelitian ini menggunakan Kuantitatif Deskriptif.

\subsection{Perumusan Masalah}

Berdasarkan latar belakang diatas permasalahan pada penelitian ini adalah bagaimana persepsi konsumen terhadap bauran pemasaran pada produk daging sapi segar di Warung Pangan Sehat Kota Bogor?

\subsection{Tujuan Penelitian}

Berdasarkan rumusan masalah diatas maka tujuan dari penelitian ini adalah mengetahui persepsi konsumen terhadap bauran pemasaran pada produk daging sapi segar di Warung Pangan Sehat Kota Bogor.

\section{TINJAUAN PUSTAKA}

\subsection{Landasan Teori}

\subsubsection{Pengertian Pemasaran}

Pemasaran adalah kegiatan manusia yang diarahkan untuk memenuhi dan memuaskan kebutuhan dan keinginan melaui proses pertukaran Assauri (2017:55). Sedangkan menurut Daryanto
(2013:1), pemasaran adalah suatu proses sosial dan manajerial dimana individu dan kelompok mendapatkan kebutuhan dan keinginan mereka dengan menciptakan, menawarkan, dan bertukar sesuatu yang bernilai satu sama lain.

Menurut Daryanto (2017:1) terdapat beberapa konsep inti pemasaran, diantaranya adalah :

a. Kebutuhan: Keadaan merasa tidak memiliki kepuasan dasar

b. Keinginan: Bentuk kebutuhan manusia yang dihasilkan oleh budaya dan kepribadian individual.

c. Permintaan: Keinginan manusia yang didukung dengan daya beli.

d. Produk: Segala sesuatu yang dapat ditawarkan kepada pasar untuk diperhatikan, dimiliki, digunakan atau dikonsumsi sehingga dapat memuaskan keinginan dan kebutuhan.

e. Nilai bagi pelanggan: Perbedaan antara manfaat yang dinikmati pelanggan karena memiliki serta menggunakan suatu produk dan biaya untuk memiliki produk tersebut.

f. Kepuasan pelanggan: Sejauh mana anggapan kinerja produk memenuhi harapan pembeli.

g. Pertukaran: Merupakan salah satu cara mendapatkan suatu produk yang diinginkan.

h. Transaksi adalah tercapainya persetujuan mengenai pertukaran.

i. Hubungan pemasaran: Proses menciptakan, memelihara dan meningkatkan hubungan erat semakin lama semakin bernilai dengan pelanggan dan pihak-pihak yang berkepentingan.

j. Pasar: Terdiri dari semua pembeli potensial yang memiliki kebutuhan dan keinginan tertentu serta mau dan mampu turut dalam pertukaran untuk memenuhi kebutuhan dan keinginan tersebut.

k. Pemasaran: Kegiatan manusia dalam hubungannya dengan pasar. 
1. Pemasar: Orang yang mencari sumber daya dari orang lain dan mau menawarkan sesuatu yang bernilai untuk itu.

\subsubsection{Pengertian Bauran Pemasaran}

Menurut Kotler dan Armstrong (2012:75), "Marketing mix is the set of tactical marketing tools that the firm blends to produce the response it wants in the target market", artinya menyatakan bahwa bauran pemasaran adalah seperangkat alat pemasaran taktis yang memadukan perusahaan untuk menghasilkan respon yang diinginkan dalam target pasar.

\subsubsection{Pengertian Produk}

Produk merupakan hasil dari proses produksi perusahaan yang nantinya akan dijual perusahaan atau barang yang dibeli untuk dijual kembali kepada konsumen akhir bagi perusahaan dagang (Daryanto, 2013:89).

Menurut Sofjan (2017:202) pada dasarnya produk yang dibeli konsumen itu dapat dibedakan atas tiga tingkatan, yaitu:

a. Produk inti (core product), yang merupakan inti atau dasar yang sesungguhnya dari produk yang ingin diperoleh atau didapatkan oleh seorang pembeli atau konsumen dari produk tersebut

b. Produk formal (formal product), yang merupakan bentuk, model, kualitas/mutu, merek dan kemasan yang menyertai produk tersebut.

c. Produk tambahan (augemented product), adalah tambahan produk formal dengan berbagai jasa yang menyertainya, seperti pemasangan (instalasi), pelayanan, pemeliharaan dan pengangkutan secara cuma-cuma.

\subsubsection{Pengertian Promosi}

Promosi adalah arus informasi atau persuasi satu arah yang dapat mengarahkan organisasi atau seseorang untuk menciptakan transaksi antara pembeli dan penjualan (Daryanto, 2013:104).

Promosi memiliki lima fungsi yang sangat penting bagi suatu perusahaan/ lembaga. Kelima fungsi tersebut dijabarkan sebagai berikut:

a. Informing (memberikan informasi), promosi membuat konsumen sadar akan produk-produk baru, mendidik mereka tentang berbagai fitur dan manfaat merek, serta memfasilitasi penciptaan citra sebuah perusahaan yang menghasilkan produk atau jasa.

b. Persuading (membujuk), media promosi atau iklan yang baik akan mampu membujuk pelanggan untuk mencoba produk dan jasa yang ditawarkan.

c. Remending (mengingatkan), iklan menjaga agar merek perusahaan tetap segar dalam para konsumen.

d. Adding value (menambah nilai), terdapat tiga cara mendasar dimana perusahaan bisa memberi nilai tambah bagi penawaran-penawaran mereka, inovasi, penyempurnaan kualitas, atau mengubah persepsi konsumen.

e. Assiting (mendampingi upaya-upaya lain dari perusahaan), periklanan merupakan salah satu alat promosi.

\subsubsection{PengertianHarga}

Harga adalah jumlah uang yang ditagihkan untuk suatu produk atau sejumlah nilai yang dipertukarkan konsumen untuk manfaat memiliki untuk menggunakan produk (Daryanto,2013:62).

\subsubsection{Pengertian Lokasi}

Lokasi adalah tempat dimana perusahaan melakukan kegiatan kerja. Kotler dan Armstrong (2012:76) dasar teori lokasi berbunyi: "Tempatkanlah pada titik geografis yang paling banayak memberi kepada perusahaan di dalam mencapai tujuan." Masalah penentuan lokasi usaha perlu mendapatkan perhatian yang serius, tiap perusahaan akan selalu berusaha 
memilih lokasi usahanya yang diperkirakan mampu memberikan keuntungan yang sebesar-besarnya.

\subsubsection{Pengertian Persepsi Konsumen}

Pengertian persepsi menurut Sheth dan Mittal (2004:129): "The process by which an individual selects, organizes, and interprets the information received from the environment." Menurut Sheth dan Mittal (2004:130), persepsi sebuah objek atau suatu peristiwa adalah hasil dari interaksi yang dipengaruhi oleh tiga faktor, yaitu: characteristic: Sumber informasi yang berasal dari lingkungan seperti objects, brands, toko-toko, marketers, teman-teman. pemerintah. Context characteristic: Kejadian ketika informasi diterima seperti kondisi sosial, kultur dan organisasi. Customer characteristic: Pengetahuan pribadi dan pengalaman termasuk keahlian customer yang relevan dengan bidang tertentu.

Persepsi adalah proses penerimaan informasi melalui lima panca indera manusia, yang kemudian diberi makna oleh konsumen. Stimuli yang didapat oleh konsumen dapat membentuk persepsi yang berbeda-beda antar konsumen yang satu dengan konsumen yang lain, oleh karena pembentukan persepsi melewati tiga proses, yaitu:

1. Selective exposure: Seseorang hanya akan menerima rangsangan yang berkenaan dengan kebutuhan dan keinginan mereka.

2. Selective attention: Seseorang hanya akan memperhatikan rangsangan yang cocok dan berkenaan dengan kebutuhan mereka.

3. Selective interpretation: Seseorang hanya akan menerima informasi yang kemudian diinterpretasikan sesuai dengan pemahamannya sendiri. Konsumen akan bertindak dan bereaksi berdasarkan atas persepsi mereka, bukan pada kenyataan yang sebenarnya dan hal itu akan mempengaruhi keputusan konsumen dalam melakukan kunjungan ulang/niat beli ulang. Jika persepsi konsumen terhadap kualitas pelayanan itu bagus, maka besar kemungkinan konsumen akan melakukan kunjungan ulang, yang berdampak terhadap loyalitas.

\subsection{Definisi Operasional}

Definisi Operasional adalah suatu definisi yang diberikan pada suatu variabel dengan member arti atau menspesifikasikan kegiatan akan membenarkan suatu operasional yang diperlukan untuk mengukur variabel tersebut.

\section{Tabel 3. Definisi Operasional}

\begin{tabular}{|c|c|c|c|}
\hline No. & Variabel & Definisi & Indikator \\
\hline \multirow[b]{3}{*}{1} & \multirow[b]{3}{*}{$\begin{array}{l}\text { Produk: } \\
\text { (X1) }\end{array}$} & \multirow{3}{*}{$\begin{array}{l}\text { Menurut Kotler \& Amstrong } \\
\text { (2001:346) Produk adalah setiap } \\
\text { apa saja yang dapat ditawarkan } \\
\text { dipasar untuk mendapatkan } \\
\text { perhatian, permintaan, pemakaian } \\
\text { atau konsumsi yang dapat } \\
\text { memenuhi keinginan atau } \\
\text { kebutuhan. }\end{array}$} & a. Kualitas produk: \\
\hline & & & $\begin{array}{l}\text { b. Keragaman } \\
\text { produk }\end{array}$ \\
\hline & & & c. Kemasan produk \\
\hline \multirow{3}{*}{2} & \multirow{3}{*}{$\begin{array}{c}\text { Promosi } \\
\text { (X2) }\end{array}$} & \multirow{3}{*}{$\begin{array}{l}\text { Menurut Kotler \& Amstrong } 2012 \\
\text { Promosi merupakan kegiatan } \\
\text { mengkombinasikan informasi dari } \\
\text { penjualan kepada pembeli atau } \\
\text { pihak lain dalam saluran untuk } \\
\text { memperngaruhi sikap dan } \\
\text { perilaku. }\end{array}$} & $\begin{array}{l}\text { a. Penayangan iklan } \\
\text { media }\end{array}$ \\
\hline & & & b. Potongan harga \\
\hline & & & $\begin{array}{l}\text { c. Update status } \\
\text { media sosial }\end{array}$ \\
\hline \multirow{3}{*}{3} & \multirow{3}{*}{$\begin{array}{l}\text { Harga } \\
\text { (X3) }\end{array}$} & \multirow{3}{*}{$\begin{array}{l}\text { Menurut Kotler \& Amstrong } 2010 \\
\text { Harga merupakan persepsi } \\
\text { konsumen atas pengorbanan } \\
\text { yang dikeluarkan untuk menilkmati } \\
\text { suatu barang. }\end{array}$} & $\begin{array}{l}\text { a. Keterjangkauan } \\
\text { harga }\end{array}$ \\
\hline & & & $\begin{array}{l}\text { b. Kesesuaian harga } \\
\text { produk dengan } \\
\text { kualitas produk }\end{array}$ \\
\hline & & & c. Daya saing harga \\
\hline \multirow{2}{*}{4} & \multirow{2}{*}{$\begin{array}{l}\text { Lokasi } \\
(\mathrm{X} 4)\end{array}$} & \multirow{2}{*}{$\begin{array}{l}\text { Menurut Kotler \& Amstrong } \\
(2012: 76) \text { Lokasi adalah tempat } \\
\text { dimana perusahaan melakukan } \\
\text { kegiatan kerja. }\end{array}$} & a. Kemudahan akses \\
\hline & & & b. Transportasi \\
\hline
\end{tabular}

\subsection{Kerangka Pemikiran}

Kerangka pemikiran merupakan model konseptual tentang bagaimana teori berhubungan dengan berbagai faktor yang telah didentifikasi sebagai masalah yang penting. Kerangka pemikiran yang baik 
akan menjelaskan secara teoritis pertautan antara variabel yang diteliti.

\section{Warung Pangan Sehat Kota Bogor}

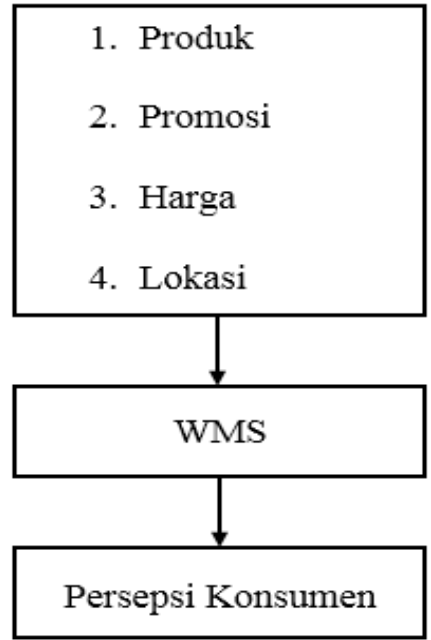

\section{Gambar 1. Kerangka Pemikiran}

\section{METODE PENELITIAN}

\subsection{Jenis Penelitian}

Jenis penelitian ini menggunakan metode kuantitatif deskriptif yang menggambarkan objek penelitian secara verbal melalui data yang telah terkumpul dan juga penyebaran angket kepada responden. Pengumpulan data dilakukan dengan cara penelitian lapangan, yaitu peneliti terjun langsung ke lokasi penelitian untuk mendapatkan data yang diperlukan.

\subsection{Variabel Penelitian}

Jadi yang dimaksud dengan variabel penelitian yang diterapkan dan dipelajari sehingga memperoleh informasi untuk menarik kesimpulan. Variabel dalam penelitian ini yaitu Bauran Pemasaran terdiri dari Produk, Promosi, Harga, dan Lokasi.

\subsection{Lokasi dan Waktu}

Lokasi yang digunakan dalam penelitian ini adalah Warung Pangan Sehat Vila Bogor Indah Kota Bogor, Jawa Barat.

Penelitian ini dilakukan selama 7 bulan yakni dimulai dari bulan Oktober 2019 hingga Mei 2020.

\subsection{Objek Penelitian}

Berdasarkan penjelasan pakar diatas maka penulis menyimpulkan objek penelitian adalah ruang lingkup yang merupakan pokok persoalan dari suatu penelitian. Dan yang menjadi objek penelitian adalah responden / konsumen Warung Pangan Sehat.

\subsection{Populasi dan Sampel}

Penelitian ini dilakukan di Warung Pangan Sehat Kota Bogor. Populasi pada penelitian ini difokuskan pada masyarakat yang membeli daging sapi yang berjumlah 2640 orang.

Dalam penelitian ini sampel diambil dengan menggunakan rumus Slovin.Pengambilan sampel ini dilakukan pada tingakat kepercayaan $90 \%$ atau nilai keritis $10 \%$ maka sampel yang akan diambil sebanyak 100 responden.

\subsection{Teknik Pengumpulan Data}

Pengambilan sampel dilakukan dengan menggunakan metode nonprobability sampling yaitu metode pengambilan sampel yang tidak memberi peluang atau kesempatan sama bagi setiap unsur atau anggota populasi untuk dipilih menjadi sampel karena pertimbangan tertentu. Metode non probability sampling ini menggunakan teknik accidental sampling.

\subsection{Jenis dan Sumber Data}

Sumber data yang digunakan dalam penelitian ini adalah :

a. Data Primer

Data Primer adalah data yang diperoleh langsung dari suatu objek yang diteliti Sugiyono (2012). Data tersebut diperoleh dari kuesioner yang diberikan kepada responden secara langsung dan hasil penelitian ini langsung dari konsumen daging sapi pada Warung Pangan Sehat Kota Bogor.

b. Data Sekunder 
Menurut Sugiyono (2012), data sekunder adalah data yang tidak langsung memberikan data kepada peneliti. Data sekunder disajikan dalam bentuk data-data, tabel-tabel bahkan dokumen mengenai topik penelitian.

\subsection{Teknik Analisis Data}

Teknik analisis data yang dilakukan berupa tabulasi data melalui software Excel 2010 yang selanjutnya dilakukan pengolahan data dengan menggunakan alat bantu aplikasi software SPSS 22.0 for Windows.

a. Uji Validitas

b. Uji Reliabilitas

c. Analisis Weight Mean Score (WMS)

4. HASIL DAN PEMBAHASAN

4.1 Data Penjualan Daging Sapi di Warung Sehat Tahun 2019

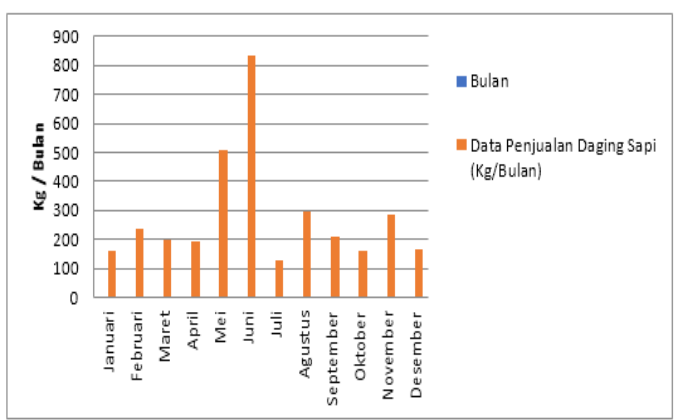

Gambar 2. Data Penjualan Daging Sapi di Warung Pangan Sehat tahun 2019

Pada gambar di atas menunjukkan pertumbuhan nilai penjualan tahun 2019 yaitu diketahui konsumsi daging sapi mengalami naik turun, dan penjualan daging mengalami kenaikan pada bulan Mei - bulan Juni 2018, yaitu saat bulan puasa dan Hari Raya Idul Fitri, yaitu sebesar $832 \mathrm{~kg}$ pada bulan Juni. Dan sampel yang diambil dari data diatas yaitu2640responden.

\subsection{Uji Validitas}

Uji Validitas digunakan untuk mengukur sah (valid) atau tidaknya suatu kuesioner. Suatu kuesioner dikatakan valid jika pertanyaan pada kuesioner mampu untuk mengungkap sesuatu yang akan diukur oleh kuesioner tersebut. Dasar pengambilan keputusan uji validitas :

a. Jika $\mathrm{r}$ hitung $>\mathrm{r}_{\text {abel }}$ maka pernyataan dinyatakan valid

b. Jika $r$ hitung $<\mathrm{r}_{\text {abel }}$ maka pernyataan tidak valid.

\section{Tabel 4. Hasil Uji Validitas}

\begin{tabular}{|c|c|c|c|c|}
\hline \multirow{4}{*}{ Variabel } & Item/ Kode & $\begin{array}{c}\text { Corrected } \\
\text { Item-Total } \\
\text { Correlation } \\
\text { r hitung) }\end{array}$ & R Tabel & Keterangan \\
\hline \multirow{4}{*}{ Produk (X1) } & X11 & 0,687 & 0,1654 & Valid \\
\cline { 2 - 5 } & X12 & 0,549 & 0,1654 & Valid \\
\cline { 2 - 5 } & X13 & 0,575 & 0,1654 & Valid \\
\cline { 2 - 5 } & $\mathrm{X} 14$ & 0,603 & 0,1654 & Valid \\
\hline \multirow{4}{*}{ Promosi (X2) } & X21 & 0,667 & 0,1654 & Valid \\
\cline { 2 - 5 } & $\mathrm{X} 22$ & 0,499 & 0,1654 & Valid \\
\hline \multirow{4}{*}{ Harga (X3) } & $\mathrm{X} 23$ & 0,675 & 0,1654 & Valid \\
\cline { 2 - 5 } & $\mathrm{X} 31$ & 0,643 & 0,1654 & Valid \\
\cline { 2 - 5 } & $\mathrm{X} 32$ & 0,635 & 0,1654 & Valid \\
\hline \multirow{3}{*}{ Lokasi (X4) } & $\mathrm{X} 33$ & 0,731 & 0,1654 & Valid \\
\cline { 2 - 5 } & $\mathrm{X} 41$ & 0,694 & 0,1654 & Valid \\
\cline { 2 - 5 } & $\mathrm{X} 42$ & 0,654 & 0,1654 & Valid \\
\hline & $\mathrm{X} 43$ & 0,564 & 0,1654 & Valid \\
\hline
\end{tabular}

Sumber : Data Primer yang diolah, 2020

Berdasarkan tabel di atas menunjukan bahwa semua indikator yang digunakan untuk mengukur variabel bauran pemasaran dan variabel keputusan pembelian yang digunakan dalam penelitian ini mempunyai koefisien kolerasi yang lebih besar dari $r$ tabel Berdasarkan hal tersebut menunjukan bahwa semua indikator pengukur variabel adalah valid.

\subsection{Uji Reliabilitas}

Uji Reliabilitas adalah suatu uji statistik untuk mengukur apakah pertanyaan/kuesioner yang diajukan 
reliable(pertanyaan yang diajukan dapat dilanjutkan ke penelitian selanjutnya/ mengetahui kekonsistenan angket). Suatu kuesioner disebut reliable (handal) jika persepsi-persepsi seseorang konsisten. Reliabillitas dapat diukur dengan jalan mengulang pernyataan/ pertanyaan yang mirip pada nomor-nomor berikutnya atau dengan jalan melihat konsistensinya (diukur dengan kolerasi) dengan pernyataan lain Dasar pengambilan keputusan uji reliabilitas :

a. Jika Cronbach's Alpha $>0,6$ maka pertanyaan realible.

b. Jika Cronbach's Alpha < 0,6 maka pertanyaan tidak realibe.

Tabel 5. Hasil Uji Reliabilitas

\begin{tabular}{|l|c|c|c|}
\hline \multicolumn{1}{|c|}{ Reliability Statistics } \\
\hline Variabel & $\begin{array}{c}\text { Cronbach's } \\
\text { Alpha }\end{array}$ & $\begin{array}{c}\text { Croanbach's } \\
\text { Alpha Based } \\
\text { on } \\
\text { Standardized } \\
\text { Items }\end{array}$ & Keterangan \\
\hline Produk (X1) & 0,704 & 0,60 & Reliabel \\
\hline Promosi (X2) & 0,661 & 0,60 & Reliabel \\
\hline Harga (X3) & 0,814 & 0,60 & Reliabel \\
\hline Lokasi (X4) & 0,748 & 0,60 & Reliabel \\
\hline
\end{tabular}

Sumber : Data Primer yang diolah, 2020

Hasil Uji reliabilitas seperti tampak pada tabel di atas menunjukan bahwa semua pengukur variabel bauran pemasaran dan variabel keputusan pembelian mempunyai koefisien Alpha yang cukup besar yaitu diatas 0,60 , atau dapat dilihat pada nilai Croanbach's Alpha, sehingga dapat dikatakan semua konsep pengukur variabel dalam penelitian ini adalah reliabel.

\subsection{Analisis Weight Mean Score (WMS)}

Skala pengukuran instrumen dari penelitian ini adalah skala Likert. Menurut Sugiyono (2010:132), "Skala Likert digunakan untuk mengukur sikap, pendapat dan persepsi seseorang atau sekelompok orang tentang fenomena sosial." Dengan menggunakan skala likert maka variabel yang akan diukur dijabarkan menjadi indikator variabel dan indikator tersebut akan dijadikan item-item instrumen yang dapat dibuat pertanyaan atau pernyataan.

Tabel 6. Analisis Weight Mean Score (WMS)Rekapitulasi Frekuensi setiap Dimensi

\begin{tabular}{|c|c|c|c|}
\hline No. & Indikator & $\begin{array}{c}\text { Nilai } \\
\text { Rata- } \\
\text { rata }\end{array}$ & $\begin{array}{c}\text { Kriteria } \\
\text { Penafsiran }\end{array}$ \\
\hline 1 & Produk & 3,48 & $\begin{array}{c}\text { Sangat } \\
\text { Baik }\end{array}$ \\
\hline 2 & Promosi & 3,42 & $\begin{array}{c}\text { Sangat } \\
\text { Baik }\end{array}$ \\
\hline 3 & Harga & 3,35 & $\begin{array}{c}\text { Sangat } \\
\text { Baik }\end{array}$ \\
\hline 4 & Lokasi & 3,31 & $\begin{array}{c}\text { Sangat } \\
\text { Baik }\end{array}$ \\
\hline \multicolumn{2}{|c|}{ Rata-rata } & $\mathbf{3 , 3 9}$ & $\begin{array}{c}\text { Sangat } \\
\text { Baik }\end{array}$ \\
\hline
\end{tabular}

Sumber : Data primer yang diolah (2020) dengan Microsoft Excel

Berdasarkan tabel 5, dapat diketahui bahawa rata-rata penilaian konsumen terhadap indikator produk keseluruhan adalah 3,48 yang berarti pada kiteria penafsiran sangat baik. Dengan demikian bahwa presepsi konsumen pada keputusan pembelian daging sapi segar di Warung Pangan Sehat dengan indikator produk adalah sangan baik.

Berdasarkan tabel 5, dapat diketahui bahwa nila rata-rata untuk penilaian konsumen terhadap indikator promosi keseluruhan adalah 3,42 yang berarti pada kriteria penafsiran sangat baik. Dengan demikian bahwa persepsi konsumen pada keputusan pembelian daging sapi segar di Warung Pangan Sehat dengan indikator promosi adalah sangat baik.

Berdasarkan tabel 5, dapat diketahui bahwa nila rata-rata untuk penilaian konsumen terhadap indikator harga keseluruhan adalah 3,35 yang berarti pada kriteria penafsiran sangat baik. Dengan demikian bahwa persepsi konsumen pada keputusan pembelian daging sapi segar di 
Warung Pangan Sehat dengan indikator harga adalah sangat baik.

Berdasarkan tabel 5, dapat diketahui bahwa nila rata-rata untuk penilaian konsumen terhadap indikator lokasi keseluruhan adalah 3,31 yang berarti pada kriteria penafsiran sangat baik. Dengan demikian bahwa persepsi konsumen pada keputusan pembelian daging sapi segar di Warung Pangan Sehat dengan indikator lokasi adalah sangat baik.

Tabel 7. Rekapitulasi Akhir Frekuensi Persepsi Konsumen

\begin{tabular}{|c|c|c|c|}
\hline No. & Indikator & $\begin{array}{c}\text { Nilai } \\
\text { Rata- } \\
\text { rata }\end{array}$ & $\begin{array}{c}\text { Kriteria } \\
\text { Penafsiran }\end{array}$ \\
\hline 1 & Produk & 3,48 & $\begin{array}{c}\text { Sangat } \\
\text { Baik }\end{array}$ \\
\hline 2 & Promosi & 3,42 & $\begin{array}{c}\text { Sangat } \\
\text { Baik }\end{array}$ \\
\hline 3 & Harga & 3,35 & $\begin{array}{c}\text { Sangat } \\
\text { Baik }\end{array}$ \\
\hline 4 & Lokasi & 3,31 & $\begin{array}{c}\text { Sangat } \\
\text { Baik }\end{array}$ \\
\hline \multicolumn{2}{|c|}{ Rata-rata } & $\mathbf{3 , 3 9}$ & $\begin{array}{c}\text { Sangat } \\
\text { Baik }\end{array}$ \\
\hline
\end{tabular}

Sumber : Data primer yang diolah (2020) dengan Microsoft Excel

Berdasarkan hasil rekapitulasi akhir yang dapat dilihat pada tabel 4.30 , analisis WMS yang dapat diketahui adalah nilai rata-rata penafsiran tertinggi yaitu pada variabel produk dengan nilai sebesar 3,48 yang berarti berada dalam kriteria penafsiran sangat baik. Sedangkan nilai rata-rata penafsiran terendah yaitu pada variabel lokasi dengan nilai sebesar 3,31 yang berarti berada dalam penafsiran sangat baik.

Dari hasil rekapitulasi tersebut diatas juga dapat diketahui bahwa analisis persepsi konsumen berdasarkan indikator dimensi secara keseluruhan diperoleh ratarata penafsiran sebesar 3,39 yang berarti sangat baik. Oleh karena itu, menunjukan bahwa secara keseluruhan persepsi konsumen terhadap bauran pemasaran pada produk daging sapi segar di Warung Pangan Sehat adalah sangat baik.

\section{KESIMPULAN DAN SARAN}

\subsection{Kesimpulan}

Berdasarkanhasildan pembahasan analisis data, maka dapat diambil beberapa kesimpulan bahwa pada hasil analisis data menggunakan Weight Mean Score (WMS). Hasilpenilaian kondisi setiap variabel yaitu variabel produk kriteria sangat baik dengan nilai rata-rata 3,48 , variabel promosi kriteria sangat baik dengan nilai rata-rata 3,42 , variabel harga kriteria sangat baik dengan nilai rata-rata 3,35 , variabel lokasi kriteria sangat baik dengan nilai rata-rata 3,31 . Nilai rata-rata penafsiran tertinggi yaitu pada variabel produk dengan nilai sebesar 3,48 yang berada dalam kriteria penafsiran sangat baik. Konsumen memiliki persepsi produk daging sapi segar yang dijual di Warung Pangan Sehat adalah sangat baik. Sedangkan nilai rata-rata penafsiran terendah yaitu pada variabel lokasi dengan nilai sebesar 3,31 yang berarti dalam penafsiran sangat baik. Konsumen memiliki persepsi lokasi Warung Pangan Sehat masih memungkinkan dijangkau konsumen. Nilai rata-rata penafsiran seluruh indikator yaitu sebesar 3,39 yang berarti sangat baik. Oleh karena itu, menunjukkan bahwa secara keseluruhan persepsi konsumen terhadap bauran pemasaran pada produk daging sapi segar di Warung Pangan Sehat dapat dinyatakan sangat baik oleh konsumen. Persepsi konsumen terhadap produk daging sapi segar dan promosi yang dilakukan Warung Pangan Sehat sangat baik. Sedangkan harga yang ditawarkan dan lokasi Warung Pangan Sehat terjangkau konsumen.

\subsection{Saran}

Berdasarkan hasil kesimpulan penelitian maka saran yang dapat penulis sampaikan adalah :

1. Penayangan promosi Warung Pangan Sehat sudah dilakukan 1 kali dalam seminggu melalui Whatsapp dan melalui media sosial lainnya. 
Berdasarkan hasil responden penayangan promosi Warung Pangan Sehat adalah rendah dan disarankan untuk meningkatkan penayangan promosi broadcast lebih dari 1 kali dalam seminggu.

2. Penayangan broadcast promosi Warung Pangan Sehat hanya berisikan teks penawaran dan disarankan menggunakan kombinasi konten teks dan media gambar atau video promosi.

3. Berdasarkan hasil responden kemasan produk Warung Pangan Sehat mudah digunakan hanya saja ukuran kemasan yang digunakan masih belum cukup untuk beberapa produk daging.

\section{DAFTAR PUSTAKA}

Assauri. S. 2017. Manajemen Pemasaran (Dasar, Konsep dan Strategi). PT Raja Grafindo Persada, Jakarta.

Daryanto. 2013. Sari Kuliah Manajemen Pemasaran. PT Sarana Tutorial Nurani Sejahtera, Bandung.

Ghozali, Imam. 2005. Aplikasi Analisis Multivariat dengan program SPSS. Semarang : Badan Penerbit Diponegoro.

Husein, Umar. 2005. Metode Penelitian. Salemba empat, Jakarta.

Kartika. 2019. Analisis Strategi Bauran Pemasaran (Marketing Mix) Sepeda United di Komunitas Gowes Ubi Gosempur Bogor. STIE Dewantara, Bogor.

Kotler. P., Keller. K. 2016. Manajemen Pemasaran Jilid 1 Edisi 13. Erlangga, Jakarta.

Kotler, Philip and Gary Armstrong. 2012. Prinsip-prinsip Pemasaran Edisi 13. Jilid 1. Jakarta: Erlangga.

Kolter, Philip and Gary Amstrong. 2001. Prinsip-prinsip Pemasaran. Edisi 13. Jilid 1. Jakarta : Erlangga.
Kolter, Philip and Gary Amstrong. 2014. Prinsip-prinsip Pemasaran Edisi 13. Jilid 1. Jakarta: Erlangga.

Saripah, Euis. 2019. Bauran Pemasaran Pada Transportasi Ojek Online (GoJek dan Grab) Terhadap Kepuasan Mahasiswa STIE Dewantara. STIE Dewantara, Bogor.

Sugiyono. 2012. Metode Penelitian Bisnis, Alfabeta, Cv. Bandung.

Sugiyono. 2013. Cara Mudah Menyusun Skripsi, Tesis, dan Disertasi (Edisi 1). Alfabeta, Bandung.

Sugiyono. 2010. Metodologi Penelitian Pendidikan Pendekatan Kuantitatif, Kualitatif dan R\&D. Alfabeta, Bandung.

Schiffman, G. Leon. 2004. Perilaku Konsumen Edisi 7. Jakarta: PT. Indeks Kelompok Gramedia. 